3. Barnett, S. (2011). The Rise and Fall of Television Journalism: Just Wires and Lights in a Box? London: Bloomsbury Academic [in English].

4. Evans, B. (2015). Mobile Is Eating the World. Retrieved from: http://ben-evans.com/benedictevans/2015/6/19/ presentation-mobile-is-eating-the-world. [in English].

5. Küng, L. (2015). Innovators in Digital News. RISJ Challenges. London: Tauris [in English].

6. Lotz, A. D. (2014). The Television Will Be Revolutionized, second edition. New York: NYU Press [in English].

7. Meeker, M. (2015). Internet Trends 2015. Retrieved from: http://www.kpcb.com/internet-trends [in English].

8. Napoli, P. M. (2011). Audience Evolution: New Technologies and the Transformation of Media Audiences. New York: Columbia University Press [in English].

9. Newman, N., Levy, D. A. L. \& Nielsen, R. K. (2015). Reuters Institute Digital News Report 2015. Oxford: Reuters Institute for the Study of Journalism. Retrieved from: http://www.digitalnewsreport.org/ [in English].

10. Nielsen, K. R. \& Sambrook, R. (2016). What is happening to television news? Oxford: Reuters Institute for the Study of Journalism [in English].

11. Westlund, O. \& Weibull, L. (2013). Generation, Life Course and News Media Use in Sweden 1986-2011. Northern Lights: Film \& Media Studies Yearbook, 11 (1), 147-173 [in English].

Стаття надійшла до редакції 20.06.2019 p.

Удк 7.01:73.03 (477)

Гончарук Олександр Віталійович.

кандидат мистецтвознавства, доцент, доцент кафедри монументально-декоративної

скульптури Львівської національної

академії мистецтв

ORCID: 0000-0002-4516-9518

sculptor.o.g@gmail.com

\title{
МОДЕРНІСТИЧНІ ПОШУКИ В СКУЛЬПТУРНИХ ПОРТРЕТАХ ХУДОЖНИКІВ - НОНКОНФОМІСТІВ ЛЬВОВА
}

\begin{abstract}
Мета роботи - осмислити основні вектори розвитку портретної скульптури Львова, дослідити модерністичні пошуки в скульптурних портретах львівських художників-нонконформістів - Я. Мотики, Р. Петрука, П.Кулика, І. Микитюка, В. Ярича. Методологія дослідження. Методологічну основу для написання роботи творять принципи історизму та системного підходу до об'єктивного висвітлення новітніх мистецьких явищ на підставі вивчення широкого кола виявлених теоретичних джерел. Згадані принципи скеровували наукову працю на комплексне застосування загальнонаукових і спеціальних мистецтвознавчих методів: художнього аналізу, герменевтики, феноменології. Наукова новизна. Проведено художній аналіз стилістичних особливостей портретної скульптури Львова кінця XX ст. в контексті ідей нонконформізму. У дослідженнях мистецтвознавців творчість художників-нонконформістів представлено в загальних рисах. Саме тому, об’єктом дослідження у статті $є$ портретна скульптура Львова кінця XX ст. Вперше визначено зміни, які відбулись у скульптурній пластиці означеного періоду, проведено аналіз низки джерел, пов'язаних з особливостями художньо-критичного осмислення складних творчих процесів, характерних для львівської портретної скульптури. Висновки. Від другої половини 80-х і упродовж 90-х років XX ст., у період Незалежності, у мистецтві відбуваються складні процеси, пов'язані зі швидким падінням систем інформаційної блокади та ідеологічного контролю, поверненням до втрачених здобутків модернізму та спробами адаптації філософоських підходів постмодернізму. Загалом, 90-ті роки минулого століття позначені істотними перемінами, які відбуваються в усіх ділянках мистецького творчості. Не оминули вони й жанру портрета, зокрема, скульптурного. Стримуване десятиліттями прагнення до сміливого пошуку та експерименту захоплює не лише колишніх нонконформістів, а й молодших художників, які формувалися на їхньому досвіді. До нього сміливо долучаються окремі автори старшої ґенерації. їхні твори, зокрема й портретні композиції, іноді лише віддалено нагадуть конкретні постаті й містять неповторні риси портретованого. Основний акцент переноситься на творення широкої гами асоціацій, де кожен глядач може обирати свій спосіб сприйняття мистецького твору. Поруч із чисто формальними вирішеннями в руслі реалістичної течії вирізняється популярний у світі гротескно-гіперреалістичний підхід до творення скульптурного портрета. Однак найбільші прояви новаторства знаходимо в художників, які починають екпериментувати на межі модернізму та постмодернізму, вживають нові, незнані досі виражальні засоби та нетрадиційні матеріали.
\end{abstract}

Ключові слова: портрет, образ, скульптура, інформація, культура, художні особливості.

Гончарук Александр Витальевич, кандидат искусствоведения, доцент кафедры монументально-декоративной скульптуры Львовской национальной академии искусств

Модернистические поиски в скульптурных портретах художников-нонконформистов Львова

Цель работы - осмыслить основные векторы развития портретной скульптуры Львова, исследовать модернистские поиски в скульптурных портретах львовских художников-нонконфоормистов - Я Мотыки, Р. Петрука, П. Кулика, И. Микитюка, В. Ярича. Методология исследования. Методологическую основу для написания работы творят принципы историзма и системного подхода к объективному освещению новейших художественных явлений на основании изучения широкого круга выявленных теоретических источников. Упомянутые принципы направляли научную работу на комплексное применение общенаучных и специальных искусствоведческих методов: художественного анализа, герменевтики, феноменологии. Научная новизна. Определены изменения, которые происходят в искусстве, где фрормируется новое пространство, в котором портретная скульптура становится объектом хранения и передачи информации. Проведен анализ целого ряда источников, связанных с особенностями художественно-критического осмысления сложных творческих процессов, характерных для львовской скульптуры рассматриваемого периода. Автором отмечено большие возможности скульптуры для создания интересных, глубоких портретных образов. Вывод. Начиная со второй половины 80-х и на протяжении 90-х годов XX в., в период Независимости, в искусстве происходят сложные процессы, связанные с быстрым падением систем информационной блокады и идеологического контроля, возвращением к утраченным достижений модернизма и попытками адаптации философских подходов постмодернизма. 90-е годы прошлого века отмечены существенными переменами, которые происходят во всех сферах художественного творчества. Не обошли они и жанр портрета, в частности, скульптурный. Сдерживаемое десятилетиями стремление к смелому 
поиску и экспериментам захватывает не только бывших нонконформистов, но и молодых художников, которые формировались на их опыте. К нему смело приобщаются отдельные авторы старшего поколения. Их произведения, в том числе и портретные композиции, иногда лишь отдаленно напоминает конкретные фигуры и содержат неповторимые черты портретируемого. Основной акцент переносится на создание широкой гаммы ассоциаций, где каждый зритель может выбирать свой способ восприятия художественного произведения. Рядом с чисто формальными решениями в русле реалистической течения отличается популярный в мире гротескно-гиперреалистичний подход к созданию скульптурного портрета. Однако проявления новаторства находим у художников, которые начинают екпериментировать на грани модернизма и постмодернизма, принимают новые, неизвестные до сих пор выразительные средства и нетрадиционные материалы.

Ключевые слова: портрет, образ, скульптура, информация, культура, художественные особенности.

Honcharuk Oleksandr, PhD, associate professor at Lviv National Academy of Arts

Modernist searches in sculptural portraits of nonconformist-artists of Lviv

Purpose of the article is to understand the main vectors of the development of portrait sculpture of Lviv, to investigate modernist searches in sculptural portraits of nonconformist artists of Lviv: Ya. Motyka, R.Petruk, P,Kulyk, I.Mykytiuk, V. Yarych. Methodology. The methodological basis for the work is the principles of historicism and a systematic approach to the objective coverage of the latest artistic phenomena on the basis of the study of a wide range of discovered theoretical sources. The mentioned principles directed scientific work on the complex application of general scientific and special art-study methods: art analysis, fenomenology, hermeneutics. Scientific novelty. Artistic analysis of stylistic features of the portrait sculpture of Lviv at the end of the twentieth century in the context of the ideas of non-conformism was conducted. In the studies of art critics, creativity of non-conformist artists is presented in general terms, that's why the object of research in the article is the portrait sculpture of Lviv at the end of the twentieth century. Changes that were made in the sculptural plastic of the marked period, an analysis of a number of sources related to the peculiarities of artistic and critical comprehension of complex creative processes typical for of Lviv portrait sculpture was carried out in this article for the first time. Conclusion. Starting from the second half of the $80 \mathrm{~s}$ and during the $90 \mathrm{~s}$, in the context of independent Ukraine complex processes associated with the rapid decline of systems of information blockade and ideological control, the return to the lost achievements of modernism and attempts to adapt the philosophical approaches of postmodernism are taking place in the art. The 90 s of the last century are marked by significant changes that took place in all areas of artistic creation. They also affected the genre of a portrait, in particular, a sculptural one. The retained for decades desire for a bold search and experiment captures not only former nonconformists but also younger artists who were formed on their experience. Some authors of older generations are boldly involved in the process. Their works, including portrait compositions, sometimes only remind remotely of specific figures and contain unique features of the portrait. The main emphasis is placed on the creation of a wide range of associations, where each spectator can choose his own way of perceiving an artistic work. Along with purely formal solutions in line with the realistic trend, the world-famous grotesque hyper realistic approach to the creation of a sculptural portrait is distinguished. However, the greatest manifestations of innovation can be found in the works of the artists who began to experiment on the brink of modernism and postmodernism, using new, still unknown yet expressive means and non-traditional materials.

Key words: portrait, image, sculpture, information, culture, artistic peculiarities.

У другій половині 80-х - 90-х роках минулого століття у мистецькому середовищі відбуваються динамічні зміни, пов'язані з розвалом радянської тоталітарної системи й швидким освоєнням безмежного інформаційного простору. Так званий творчий метод соцреалізму втрачає провідні позиції, а незабаром відходить у небуття. Спостерігається своєрідна реанімація мистецьких течій модернізму і на перший план поступово виходить творчість художників-нонконформістів. Закономірно, що в скульптурі найбільшу інтригу складає звернення до новітніх формотворчих принципів, які відкрив на початку XX століття О. Архипенко. Однак мистецьке середовище, як і українські мистецькі навчальні заклади, виявляються неготовими до широкомасштабної адаптації ідей геніального скульптора. У сферах скульптури помітна інерція минулого, схильність до реалізму, простого й зрозумілого широким верствам художників і глядачів. Усе це повною мірою стосується жанру скульптурного портрета. Водночас з'являється плеяда скульпторів середнього й молодого поколінь, які ведуть сміливий пошук не лише в мистецьких течіях модернізму, а й намагаються експериментувати в цілком новому філософськоестетичному руслі постмодернізму.

В українському мистецтвознавстві останніх десятиліть спостерігається посилений інтерес до портретної скульптури, що стала предметом дослідження сучасних науковців. Особливе значення для дослідження львівської портретної скульптури пострадянського періоду мають видання кінця 1980-х 1990-х років: каталоги персональних та групових виставок з вступними статтями, буклети, збірники, альманахи та статті в періодиці. Розвиток портретної скульптури Львова в контексті новітніх історичних досліджень $є$ характерним прикладом загальних тенденцій, що, за думкою цілого ряду дослідників (Л. Турчак [10], Н. Журмій [5], О. Голубця [1; 2; 3], Д. Крвавича [6], С Лупій [7], та ін.), в цілому відрізняють вітчизняний мистецтвознавчий дискурс. Аналіз таких пам'яток, поки що лишається фрагментарним та не надто системним. Переважно дослідників цікавлять творчі пошуки окремих митців, або проблеми розвитку регіональних шкіл та напрямів.

3 моменту, коли в Львівському державному інституті прикладного й декоративного мистецтва після «засудження проявів формалізму» був закритий відділ скульптури (так само, як і відділ живопису), когорту кращих художників у цій сфері творчості почали регулярно поповнювати випускники кафедри художньої кераміки. Частина з них постійно працювала в скульптурі, інші свідомо залишалися працювати в напрямі декоративно-ужиткового мистецтва. Тут вони отримували значно ширший простір для творчих пошуків і експериментів.

До перших належить Я. Мотика, творчості якого притаманна глибока філософрія творення, втілена в простих, на перший погляд, просторових композиціях. Його роботи сформовані ніби без надмірних зусиль, кількома штрихами вправних рук митця. Вони цілком позбавлені деталізації, а нерідко й достовірності анатомічних пропорцій. Водночас у них завжди вгадується яскравий образ портретованого, де характерні риси можуть набирати гротескової гіперболізації. Митець $є$ одним 3 
небагатьох українських скульпторів, хто послідовно дотримується пластичних концепцій геніального О. Архипенка.

Власні скульптурні підходи Я. Мотика почав реалізовувати ще за радянських часів, однак тоді його твори могли бути зараховані до «шкідливого формалізму». Природно, що скульптуру такого плану не експонували на офіційних виставках. Крім того, важливо зазначити ще один момент: більшість композицій художник виконував у керамічних матеріалах - чорнодимленій теракоті чи шамотній масі. Пізніше автор нерідко випалював готові роботи разом з традиційними виробами народних майстрів у примітивних стародавніх печах, у здавна відомому на Львівщині осередку - Гавареччині. Тут скульптор реалізував багато творчих задумів. Його роботи завжди вирізнялися активним пластичним моделюванням, підкресленою експресивністю ручного ліплення. Невипадково багато творів Я. Мотики нині зберігаються в колекціях львівських музеїв. Серед них - керамічні скульптури «Т. Шевченко» (1980), «За гончарним кругом» (1980), «Козак Мамай» (1981), «До народного джерела» (1981), «Троїсті музики» (1982), «Сільський мудрець» (1983), «Гончар Мар'ян Бакусевич» (1983), «Козак з човном» (1983).

Нагадаємо про дві роботи митця - портрети видатних, знакових для львівського мистецького середовища постатей. Перший - шамотне погруддя відомого львівського художника Романа Сельського (1980). Ледь нахилена вправо голова й рука у виразному жесті відтворюють неповторну індивідуальність митця, якого знали й шанували у Львові, його високу інтелігентність, мудрість, скромність і витончену натуру. Високе чоло, ледь примружені глибокі очі, масивний ніс із горбинкою, тонкі вуста й гостре підборіддя формують риси обличчя. Видовжений, гранчастий об'єм голови доповнює хвилясте волосся. Активно акцентує скульптор витончену кисть руки митця - тонкі, довгі, як у музиканта, пальці ледь зігнуті, ніби в роздумах торкаються до шиї. Діагональному руху голови й руки вдало протиставлена горизонталь плечового поясу. У портреті Романа Сельського скульпторові вдалося дуже влучно передати натуру та індивідуальні риси митця, вловити ту його неповторну мистецьку силу та «інакшість», які допомагали опиратися середовищу, де безроздільно панували ідеологічні постулати.

3-поміж чималого переліку творчих робіт Я. Мотики вирізняються ті, які сміливо можна зарахувати до кращих образів видатних людей сьогодення. Однією з них є скульптурний портрет довголітнього директора Львівської національної галереї мистецтв, Героя України Бориса Возницького. На зламі 90-х - 2000-х років портрет був виконаний у шамоті, невдовзі переведений у бронзу (2011).

Ще одна яскрава постать - Р. Петрук, якого тривалий час не допускали до офіційного грона львівських скульпторів. Хоча «творчі здобутки митця дають підставу відносити його до числа кращих українських пластиків XX століття він з однаковим успіхом працює в кераміці, дереві, гіпсі чи бронзі ... здається, що практично будь-який матеріал в руках митця може стати активним співучасником творення образу» $[1,98]$.

Митець був єдиним скульптором серед учнів, які в радянський час навчалися в нелегальній мистецькій школі К. Звіринського. Його професійна майстерність зростала поруч з А. Бокотеєм, О. Крип'якевич, Л. Медведем, О. Міньком, 3. Флінтою. На перший погляд, здається, що художника зовсім не цікавить досконалість зовнішньої поверхні скульптури. Вона формується немов би якось недбало, у процесі вияву внутрішньої динаміки, експресії. Герої створюваних композицій цілком нетипові, у них відсутня характерна для радянських часів надумана монументалізація. Вони захоплюють глядача добродушною теплотою, легкими гротескними інтонаціями $[1,95]$.

Неповторний талант художника вповні розкрився в 90-х роках, коли він отримав змогу створити низку об'ємно-пластичних композицій, безпосередньо пов'язаних з архітектурними будівлями й природним середовищем. Яскравими зразками є скульптурний ансамбль «Вертеп» (1990-2000) на території санаторію «Карпати» та каплиця «Живе джерело» (1998-2000) у Трускавці. Хоча в обох випадках ми маємо справу з повнофігурними постатями, їхні портретні характеристики викликають особливе зацікавлення [1, 97].

Помітною постаттю в середовищі львівського нонконформізму $є$ П. Кулик. Його творчість також значною мірою ґрунтується на пластичних візіях знаменитого О. Архипенка й традиціях українського аванґарду. Цьому напряму художник завжди був вірним, навіть коли завершилися творчі пошуки періоду «відлиги» і знову запанувала тенденція повернення до соцреалізму. Митець надалі розвивав ідеї чистої пластичної форми, наповненої неймовірною внутрішньою силою. Саме на цій основі зароджується його образ Івана Підкови. На довгі роки він займе особливе місце у творчості художника, мабуть тому, що відповідає його внутрішній суті, нескоренній козацькій натурі, ідеї непокори, пожертви й життєвого драматизму.

Над образом козацького ватажка П. Кулик працював понад десять років. Перед встановленням першого пам'ятника була виготовлена низка станкових творів. Очевидно, офіційного дозволу на здійснення свого задуму скульптор не міг отримати, а тому на початку 80-х років зумів скористатися слушною нагодою: влада Львова запропонувала художникам подарувати місту свої твори. Більшість авторів, однак, не виявили бажання, а П. Кулик відгукнувся і зробив «подарунок», від якого радянська влада вже не змогла відмовитися (1982).

Через кілька років бронзове погруддя Івана Підкови було урочисто встановлене на сході України, спочатку в Черкасах (1987), а після тривалого перебування митця в Канаді оригінальна фрігура з бронзи й граніту була зведена в Каневі (2000). 
Варто також згадати пам'ятник Іванові Франку, який П. Кулик виконав у Торонто (1992). Півфрігура Каменяра подана в динамічному повороті. Одна рука спирається на книжку, інша - відкинута назад. Маса тулуба, складки піджака максимально узагальнені. Декоративним акцентом звучить лише вишивка на сорочці, позначена легким плоским рельєфом. Вінчає вертикаль пам'ятника голова на міцній шиї.

Від другої половини 80-х років починають творити скульптори, які під час «відлиги» були ще юнаками, однак помисли «шістдесятників», ідеї нонконформізму стали для них основними надалі [4, 32-38]. Так, творчий розквіт І. Микитюка розпочинається в роки незалежності [8]. Він завжди приділяв особливу увагу природній красі матеріалу - холодного й важкого каменя, легкої, теракоти чи шляхетної бронзи. Саме ця краса формувала багатий авторський арсенал виражальних засобів, які ніби легко та органічно виходили з пластичної маси. Захоплюючись творчістю модерністів, серед яких чи не найважливіше місце займали Роден і Манцу, художник уникає інертних вигладжених площин. Його скульптурна пластика сприймається як безконечне поле вільної імпровізації, сповненої динамічних рухів і живих, щирих емоцій $[8,25-30]$.

Провідне місце в творчості І. Микитюка посідає образ людини, але не стандартно-типовий, як колись цього вимагала панівна система, а складний, сповнений пошуків для відтворення внутрішнього психологічного стану конкретного індивідуума. Його цікавить людина з усіма її переживаннями, комплексом негативних і позитивних рис, сподівань і роздумів. Живо реагуючи на актуальні проблеми сьогодення, митець ніколи не втрачає глибинних зв'язків з народними традиціями [8]

Скульптор намагається надавати своїм героям неповторності й життєвої правди, органічного поєднання внутрішньої краси та зовнішньої простоти, а глядачеві - здатності активного співпереживання зображуваного. Нерідко автор творить узагальнені образи, позбавлені конкретики - «Чоловічий портрет» (1987), «Дума про Берестечко» (1987), «Портрет юнака» (1987), «Сільський філософф» (1988), «Великий філософр (1989), «Козацький мотив» (1989), «Мудрець» (1991), портрети з циклу «Мої однокласники» (1999-2000) та ін. Водночас є в доробку митця й конкретні портретні зображення, як, наприклад, «Народний артист України Ф. Стригун» (1987) чи «Ю. Федькович» (1989) $[8,25-30]$.

У скульптурному погрудді «Дума про Берестечко» І. Микитюк передав одну з багатьох сторінок трагічної історії українського народу, його героїчних подвигів і звитяг. Потужна енергетика, незламність духу, віра в перемогу закладені в композиційному авторському задумі та втілені через символічний образ козака. Інші інтонації звучать у емоційно стриманій роботі «Сільський філософ». У ній авторові вдалося створити узагальнений образ простої та водночас незвичайної людини - сільського мудреця. Художник відтворив образ сільської інтелігенції, якою були сповнені українські села в час існування у них широкої мережі «Просвіти». Неодмінною складовою композиційного задуму став сам матеріал, адже портрет виконано у вигляді чорнолощеної кераміки, встановленої на масивній дерев'яній підставці.

Набутий досвід і глибина авторського мислення І. Микитюка знайшли втілення у скульптурному портреті, названому «Великий філософ». Художник намагається зрозуміти й передати глибину та природну життєву мудрість людини-творця, людини-філософа. Він ніби спеціально протиставляє зовнішні та внутрішні характеристики портретованого. Так, за зовнішньою простотою, дещо здеформованим обличчям проглядається глибокий спокій, душевна рівновага. Скульптор майстерно розставив обрані акценти, деталізуючи образ і, водночас, узагальнюючи його. Образ «Великого філософа» на диво лаконічний і виразний, сповнений внутрішньої духовної краси, віри в споконвічні загальнолюдські цінності.

Активна творча позиція І. Микитюка впродовж 90-х років ніби вела його до визначного здобутку - роботи над унікальним пам'ятником Тарасові Шевченку в Будапешті (встановлений 2007 року). Професійна майстерність скульптора знайшла тут повне й досконале втілення. Найважливішу складову створеної фрігурної композиції фігури Кобзаря творить, безумовно, глибокий психологічний портрет $[8,10-30]$.

Творча активність В. Ярича наростає впродовж 80-х років. Його перші портрети - «Малий Петро» (1981), «Світлана» (1980), «Дівчина з голубом» (1984), «Михайло» (1985). Надалі він неодноразово звертається до історичної тематики, до відображення великих постатей української історії та культури. Так, у портреті Юрія Дрогобича (1981) скульптор зумів прекрасно передати дух і настрій епохи, у якій судилося жити й працювати великому гуманістові. Інші його герої - великий маляріконописець кінця XVII століття, родом із Жовкви, Іван Руткович, філософр Г. Сковорода, письменники В. Стефаник, М. Коцюбинський. У цих портретах автор оптимально акцентує саме ті прийоми та мистецькі засоби, які найбільше відповідають авторському баченню [11].

Митець постійно експериментує, шукає нові пластично-образні можливості, що збільшують гаму асоціацій. Привертає, зокрема, увагу портрет під назвою «Осінь» (1983). Схоже на маску обличчя, прикриті очі повернені до глядача в складному ракурсі схиленої голови. Виразності й психологічного забарвлення твору додає активний рисунок текстури алебастру [9, 18-25].

Інші настрої панують у «Портреті молодого художника» (1986). Тут скульптор звертається до класики: манера виконання погруддя виявляє очевидні паралелі з найкращими зразками римського 
портрета доби античності. Самозаглиблений вираз обличчя, ледь вловимий порух голови, міцно стулені вуста фріксують стан натхнення, напружених пошуків і внутрішніх переживань молодого художника. Природне забарвлення бронзи, доповнене певними нюансами її патинування, вдало посилює загальне емоційне звучання твору [4, 32-38].

Творчий доробок В. Ярича 80-х років вирізняється не лише авторськими образно-пластичними прикметами. Він став чи не першим львівським скульптором, хто портретні композиції майже завжди представляє не в тонованому гіпсі, а в твердому матеріалі: дереві, бронзі, мармурі, камені тощо. При цьому матеріал стає суттєвим чинником посилення образної виразності. Творчість В. Ярича 90-х років позначена особливою інтенсивністю та образним багатством. На персональних виставках у Львові (1991) та Києві (1992) художник представив серед інших робіт портрети, позначені характерними якісними змінами - значно виразнішою стилізацією форм, ускладненістю композиційних вирішень, використанням продуманого зіставлення гладких і фактурно збагачених площин. Створені впродовж означеного десятиліття портретні зображення митрополита Андрея Шептицького (1991), Соломії Крушельницької (1991), Михайла Грушевського (1991), Михайла Коцюбинського (1991), Йосифа Сліпого (1992), Івана Франка (1996), Степана Бандери (1996), Михайла Вербицького (1997), Петра Кіщака (1999) демонструють звернення до славного минулого України. В історичних постатях автор прагне втілити фрілософський зміст, морально-етичну глибину проблем, які осмислює кожне покоління. Прикметним у аспекті сказаного є, зокрема, портрет Максима Кривоноса $(1999)[11,3]$.

Період наполегливого творчого пошуку передував створенню портрета Соломії Крушельницької. В. Ярич створив яскравий образ співачки, якою можуть пишатися і українці, і поляки.

Підсумовуючи відзначимо, що львівське мистецьке середовище рясніє художниками, яких за радянських часів не могли зачислити до скульпторів, але які, однак, можуть вважатися одними з кращих пластиків сучасності.

\section{תimepamypa}

1. Голубець О. Відступ у тінь: Скульптор Роман Петрук. Музейний провулок. 2006. № 1. С. 98-110.

2. Голубець О. Між свободою і тоталітаризмом. Львів : Академічний експрес, 2001. 175 с.

3. Голубець О.Сучасна скульптура Львова. Львів : БАК, 2015. 144 с.

4. Гончарук О. Портретна скульптура Львова 90-х років XX сторіччя у контексті часу. Вісник Харківської державної академії дизайну і мистецтв. 2016. № 1. С. 32-38.

5. Журмій Н. Міська скульптура як матеріальний вираз суспільної пам'яті. Культурна політика у контексті полікультурного світу : матеріали Всеукраїнської наук.-практ. конференції, 29-30 вересня 2011. Київ, 2012. Ч. 1. С. 97-98.

6. Крвавич Д., Черепанова С. Мистецтво скульптури. Українське мистецтво : навч. посібник / за ред. Крвавич Д.П., Овсійчук В.А., Черепанова С.О. : у 3 т. Львів : Світ, 2005. Т.3. С.184-213.

7. Лупій С. Митець і його час. Скульптор Євген Дзиндра. Образотворче мистецтво. 2002. № 3. С. 25-26.

8. Микитюк І. Скульптура : каталог / вступ. стаття О. Голубець. Львів : б. в. 2003. - 30 с.

9. Стельмащук Г. Василь Ярич. Львівська мозаїка. Образотворче мистецтво. 2007. № 2. С. 18-25.

10. Турчак Л. Процеси змін в українській скульптурі (сучасний аспект). Художня культура України. Актуальні проблеми / ред. О. Федорук, В. Сидоренко, І. Безгін та ін. ; Інститут проблем сучасного мистецтва Академії мистецтв України. Київ, 2008. Вип. 5. С. $188-196$.

11. Ярич В. Скульптура. Мої пороги: альбом / за ред. М. Маричевського. Київ : Софія-А, 2004. 128 с.

\section{References}

1. Holubets, O. (2006). Vidstup u tin: Skulptor Roman Petruk. Muzeinyi provulok., 1. 98-110. [In Ukrainian].

2. Holubets, O. (2001). Mizh svobodoiu i totalitaryzmom. Lviv : Akademichnyi ekspres. [In Ukrainian].

3. Holubets, O. (2015). Suchasna skulptura Lvova. Lviv : BAK. [In Ukrainian].

4. Honcharuk, O. (2016). Portretna skulptura Lvova 90-kh rokiv XX storichchia u konteksti chasu. Visnyk Kharkivskoi derzhavnoi akademii dyzainu i mystetstv, 1. 32-38. [In Ukrainian].

5. Zhurmii, N. (2012). Miska skulptura yak materialnyi vyraz suspilnoi pamiati. Kulturna polityka u konteksti polikulturnoho svitu: materialy Vseukrainskoi nauk.-prakt. konferentsii. Kyiv, 1. 97-98. [In Ukrainian].

6. Krvavych, D., \& Cherepanova S. (2005). Mytets i yoho chas. Ukrainske mystetstvo. Krvavych D., Cherepanova S., \& Ovsiichuk V. (Eds.). (Vols. 1-3; Vol. 3, pp. 184-213). Lviv : Svit. [In Ukrainian].

7. Lupii, S. (2002). Mytets i yoho chas. Skulptor Yevhen Dzyndra. Obrazotvorche mystetstvo, 3. 25-26. [In Ukrainian].

8. Mykytiuk, I. (2003). Skulptura : kataloh. Lviv. [In Ukrainian].

9. Stelmashchuk, H. (2007). Vasyl Yarych. Lvivska mozaika. Obrazotvorche mystetstvo, 2. 18-25. [In Ukrainian].

10. Turchak, L. (2008). Protsesy zmin v ukrainskii skulpturi (suchasnyi aspekt). In Khudozhnia kultura Ukrainy. Aktualni problemy, 5. 188-196. [In Ukrainian].

11. Yarych, V. (2004). Skulptura. Moi porohy: album. M. Marychevskyi (Ed.). Kyiv : Sofiia-A. [In Ukrainian]. 